\title{
Corneal melanosis successfully treated using topical mitomycin-C and alcohol corneal epitheliectomy: a 3-year follow-up case report
}

\author{
Tratamento com êxito da melanose de córnea utilizando mitomicina-C tópica e epiteliectomia auxiliada \\ por álcool: relato de caso com três anos de seguimento
}

Mehmet Balcl ${ }^{1}$, Ramazan YaĞcl ${ }^{2}$, Emre Güler ${ }^{3}$, Hacer Haltaş $^{4}$, Rahmı Duman ${ }^{1}$, İ Brahim F. Hepşen $^{5}$

\begin{abstract}
We report a case of primary acquired corneal melanosis without atypia associated with corneal haze in a patient with a history of limbal malignant melanoma and the effect of mitomycin-C. A 75-year-old woman with a history of limbal malignant melanoma presented with loss of vision in right eye. Corneal examination showed a patchy melanotic pigmentation with a central haze. Topical mitomycin-C improved visual acuity and corneal haze. However, the pigmented lesions persisted and they were removed with alcohol corneal epitheliectomy. Histopathological examination demonstrated primary acquired melanosis without atypia. The lesions were successfully removed, and there were no recurrences during the follow-up period of 36 months. The association of conjunctival and corneal melanosis without atypia is a rare condition. In addition, co-existence of central corneal haze and melanosis may decrease visual acuity. Topical mitomycin-C and alcohol corneal epitheliectomy can be useful treatments in this condition.
\end{abstract}

Keywords: Epiteliectomia; Álcool; Cicatrização da córnea; Melanose córnea; Melanoma maligno; Mitomicina-C

\section{RESUMO}

Relatar um caso de melanose adquirida primária de córnea sem atipia, associado a haze corneano em um paciente com história de melanoma maligno de limbo e o efeito da mitomicina-C. Uma mulher de 75 anos de idade, com história de melanoma maligno do limbo apresentado com diminuição de visão no olho direito. O exame de córnea mostrou uma pigmentação melânica irregular com um haze central. 0 uso de mitomicina-C tópica levou à melhora da acuidade visual e da opacidade corneana. No entanto, as lesões pigmentadas persistiram e foram removidas com epiteliectomia associada ao álcool. O exame histopatológico demonstrou melanose adquirida primária sem atipia. As lesões foram removidas com êxito, e não houve recidiva durante o perío do de acompanhamento de 36 meses. A associação melanose sem atipia da conjuntiva e da córnea é uma condição rara. Além disso, a coexistência de haze corneano central e melanose pode diminuir a acuidade visual. O uso de mitomicina-C tópica e epiteliectomia corneana auxiliada pelo álcool podem ser tratamentos úteis nessa situação.

Descritores: Epitheliectomy; Alcohol; Corneal haze; Corneal melanosis; Malignant melanoma; Mitomycin-C

\section{INTRODUCTION}

Conjunctival and corneal pigmented lesions, ranging from benign to malign lesions, are observed in numerous conditions including nevus, primary acquired conjunctival melanosis (PAM) with and without atypia, and malignant melanoma. PAM is an important benign pigmented condition that can result in melanoma, and it is most common in middle-aged or elderly Caucasian individuals ${ }^{(1)}$. The histological appearance of melanocytic proliferation including melanocytes with atypical features found in all levels of the epithelium is observed in PAM with atypia and that of melanocytes lacking atypical features is observed in PAM without atypia ${ }^{(2)}$. In this case report, we present a corneal PAM without atypia in a patient with a history of limbal malignant melanoma.

\section{CASE REPORT}

A 75-year-old woman presented with blurred vision, excessive tearing, and photophobia in the right eye. The patient had undergone a nasal conjunctival malignant melanoma excision, without adjuvant cryotherapy or chemotherapy, performed by an outside surgeon, 18 months earlier. Upon examination, her visual acuity was 1/10 in the right eye. Slit-lamp examination showed a patchy melanotic pigmentation covering the upper-nasal limbal quadrant, periphery, and mid-periphery of the cornea, without corneal vascularization and corneal epithelial defect. In addition, a central corneal haze was observed in the same eye (Figure 1). The initial treatment included topical mitomycin-C (MMC), fluorometholone acetate, and artificial tears. Topical 0.04\% MMC was applied four times daily for 1 week. Then, MMC was discontinued for 1 week. Her symptoms resolved, visual acuity improved, and the corneal haze disappeared after the application of this regimen four times (Figure 2). However, the pigmented lesions persisted. Therefore, we excised the corneal epithelium and underlying pigmented layer using alcohol corneal epitheliectomy. Histopathological examination demonstrated PAM without atypia (Figure 3). The lesions were successfully removed, and there were no recurrences during the follow-up period of 36 months (Figure 4). At her last visit (at 36 months), the visual acuity was 10/10 in the right eye.

\section{DISCUSSION}

The most important lesions arising from the melanocytes of the conjunctiva and episclera are nevus, racial melanosis, PAM, and
Submitted: August 25, 2014

Accepted: December 1, 2014

Department of Ophthalmology, Abdurrahman Yurtaslan Oncology Training and Research Hospital, Ankara, Turkey.

Department of Ophthalmology, Medical School, Pamukkale University, Denizli, Turkey.

Eye Clinic, Erciş State Hospital, Van, Turkey.

${ }^{4}$ Department of Pathology, Medical School, Fatih University, İstanbul, Turkey.

${ }^{5}$ Department of Ophthalmology, Gazi University, Medical School, Ankara, Turkey.
Funding: No specific financial support was available for this study

Disclosure of potential conflicts of interest: None of the authors have any potential conflict of interest to disclose.

Corresponding author: Emre Güler. Van Yolu Caddesi 65400. Erciş/VAN - Turkey E mail: guleremre83@hotmail.com 


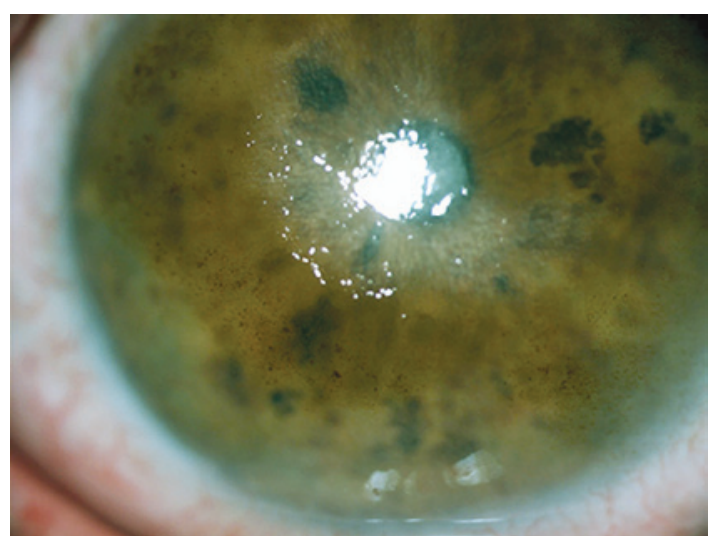

Figure 1. Melanotic pigmentation of the peripheral cornea and central corneal haze.

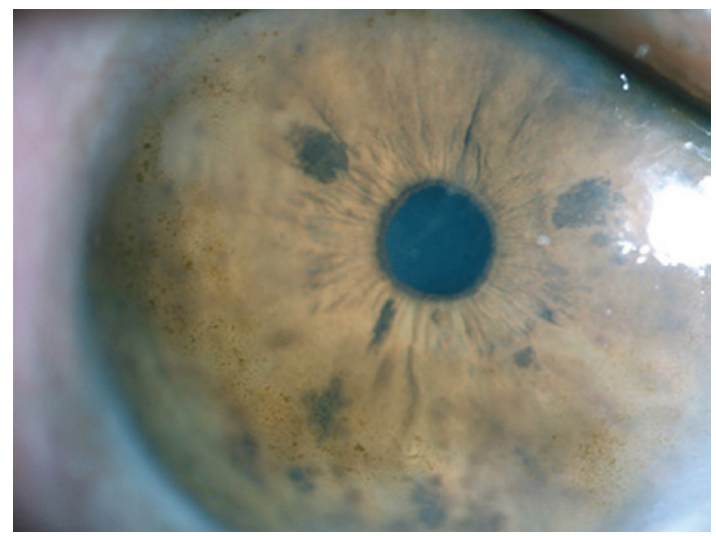

Figure 2. The central corneal haze healed within 1 month after MMC treatment.

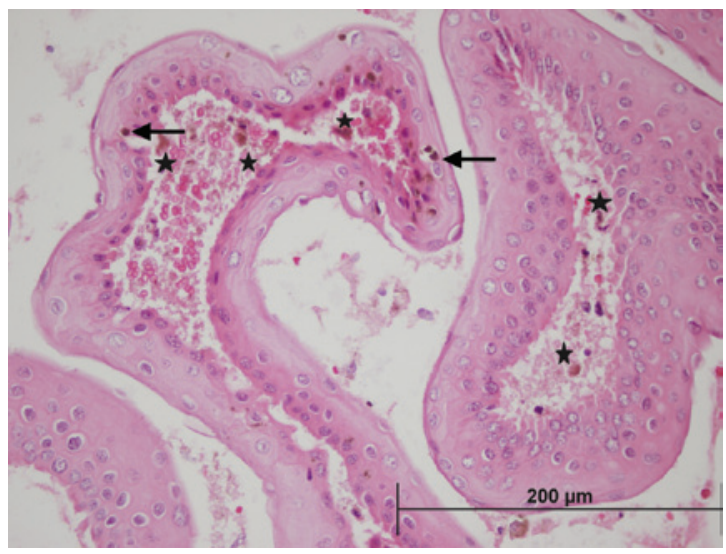

Figure 3. Dense pigmentation (stars) at the basal layer of the epithelium, with a normal number of melanocytes (arrows) without any cellular atypia (Hematoxylin-Eosin staining).

malignant melanoma. PAM is classified as with or without atypia. The clinical appearance of conjunctival PAM is unilateral and conjunctival, and it is rarely associated with corneal melanotic macule developing in the elderly. The pigmentation tends to be irregular and waxy and gradually becomes more extensive and multifocal. Histologically, diffuse, intraepithelial melanocytic proliferation can be observed, with increased numbers of melanocytes confined to the basal layer of the conjunctival epithelium. These melanocytes are either normal

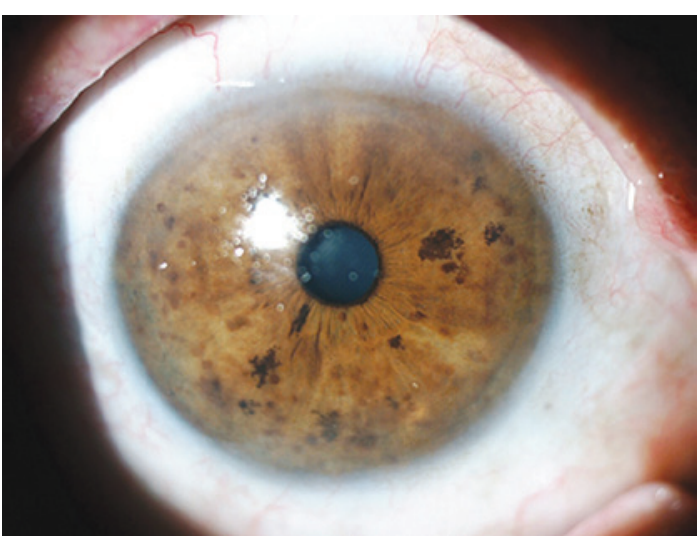

Figure 4. The disappearance of lesions 2 months after alcohol corneal epitheliectomy.

or hypertrophic, possibly with an increased number of dendrites, showing no cytological features of atypia or malignancy ${ }^{(3)}$.

Small lesions of PAM are often managed initially by observation. Lesions with changes or extensive lesions should be biopsied. At least 35\% of PAM lesions progress clinically, and at least 11\% develop into melanomas within 10 years ${ }^{(1,4)}$. PAM without atypia is not considered a premalignant lesion and does not require treatment. PAM with atypia carries a risk of malignant transformation. The extent of PAM, measured in clock hours, best correlates with the risk of transformation into melanoma ${ }^{(1,4)}$. Small lesions $(<1$ clock hour) can be followed up by clinical observation. Larger lesions are generally treated by surgical excision and cryotherapy. Oral mucosal or amniotic membrane grafting may be required to fill defects after larger excisions. Unresectable or recurrent diffuse PAM with atypia is managed by mapping biopsies and cryotherapy or MMC and close clinical follow-up ${ }^{(1,4)}$.

Two notable features of this case should be emphasized. First, the association of conjunctival and corneal melanosis, a rare condition, was observed. Moreover, Shields et al. have reported a case of conjunctival melanosis with atypia involving the cornea that was completely healed with topical application of $M_{M M C}{ }^{(5)}$. Another case of melanokeratosis due to chronic trauma showed recurrence during follow-up of alcohol corneal epitheliectomy ${ }^{(6)}$. Second, the co-existence of central corneal haze and melanosis, which may have decreased the best-corrected visual acuity, was observed. The haze completely disappeared, and visual acuity improved because of the MMC treatment within 1 month. However, the melanosis persisted; therefore, we performed alcohol corneal epitheliectomy. We observed no recurrence in the 3-year follow-up period after epitheliectomy.

In conclusion, we present this case to illustrate that PAM without atypia can occur in the cornea and cause complaints. Topical MMC and alcohol corneal epitheliectomy can be useful treatments in this condition.

\section{REFERENCES}

1. Zembowicz A, Mandal RV, Choopong P. Melanocytic lesions of the conjunctiva. Arch Pathol Lab Med 2010;134(12):1785-92

2. Shields CL, Shields JA. Tumors of the conjunctiva and cornea. Surv Ophthalmol 2004 49(1):3-24.

3. Damato B, Coupland SE. Conjunctival melanoma and melanosis: a reappraisal of terminology, classification and staging. Clin Experiment Ophthalmol 2008;36(8):786-95

4. Shields JA, Shields CL, Mashayekhi A, et al. Primary acquired melanosis of the conjunctiva: experience with 311 eyes. Trans Am Ophthalmol Soc 2007;105:61-71; discussion 71-2.

5. Shields CL, Demirci H, Shields JA, et al. Dramatic regression of conjunctival and corneal acquired melanosis with topical mitomycin C. Br J Ophthalmol 2002;86(2):244-5.

6. Boto-de-Los-Bueis A, Díaz-Valle D, Llorente-González S, et al. Post-traumatic striate melanokeratosis in a Caucasian woman. Arch Soc Esp Oftalmol 2009;84(4):213-5. Spanish. 